\title{
Physiological responses of soybean (Glycine max (L.) Merrill) cultivars to copper excess
}

\author{
RAISSA SCHWALBERT ${ }^{1}$, LINCON O.S. SILVA ${ }^{2}$, RAI A. SCHWALBERT ${ }^{3}$, CAMILA P. TAROUCO ${ }^{1}$, \\ GILLIAN S. FERNANDES ${ }^{1}$, ANDERSON C.R. MARQUES ${ }^{1}$, CAMILA C. COSTA ${ }^{1}$, RODRIGO \\ K. HAMMERSCHMITT ${ }^{2}$, GUSTAVO BRUNETTO ${ }^{2}$ and FERNANDO T. NICOLOSO ${ }^{1}$ \\ ${ }^{1}$ Departamento de Biologia, Centro de Ciências Naturais e Exatas, Universidade Federal \\ de Santa Maria, Av. Roraima, 1000, 97105-900 Santa Maria, RS, Brazil \\ ${ }^{2}$ Departamento de Solos, Centro de Ciências Rurais, Universidade Federal de Santa \\ Maria, Av. Roraima, 1000, 97105-900 Santa Maria, RS, Brazil \\ ${ }^{3}$ Agronomy Department, Kansas State University, Claflin Road, 1712, 66502 Manhattann, Kansas, USA \\ Manuscript received on February 01, 2019; accepted for publication on June 17, 2019
}

\begin{abstract}
How to cite: SCHWALBERT R, SILVA LOS, SCHWALBERT RA, TAROUCO CP, FERNANDES GS, MARQUES ACR, COSTA CC, HAMMERSCHMITT RK, BRUNETTO G AND NICOLOSO FT. 2019. Physiological responses of soybean (Glycine max (L.) Merrill) cultivars to copper excess. An Acad Bras Cienc 91: e20190121. DOI 10.1590/0001-3795201920190121.
\end{abstract}

\begin{abstract}
Successive applications of copper fungicides on vines have resulted in increased copper content in vineyard soils over the years. This high copper content has affected the growth of young vines in eradicated vineyards. Thus, the cultivation of annual species for a few years is an alternative to copper phytostabilization, because it would be a good way to decrease copper availability to plants. The aim of this study was to evaluate the physiological responses of different soybean cultivars to copper concentration increase. Four different soybean cultivars were grown under three copper concentrations: 0.5, 20 and 40 $\mu \mathrm{M}$ in nutrient solution. The main outcomes of this study were: i) Cultivar M 6410 IPRO recorded the highest photosynthetic rate when plants were exposed to $40 \mu \mathrm{M}$ of copper in the nutrient solution; ii) plants in cultivar M 6410 IPRO accumulated large copper concentrations in their roots although did not decrease the root dry mass, possibly due to the higher superoxide dismutase activity; iii) cultivar DM 5958 RSF IPRO recorded drastically reduced photosynthetic rate and dry mass production due to copper excess. We conclude that each cultivar responded differently to the excess of copper, but none of them showed tolerance to it.
\end{abstract}

Key words: antioxidant system, cash crops, heavy metal phytostabilization, photosynthesis.

\section{INTRODUCTION}

Successive applications of copper $(\mathrm{Cu})$ fungicides on vines have resulted in increased $\mathrm{Cu}$ content in vineyard soils over the years (Brunetto et al. 2014). Grape yield decreases due to vine aging,

Correspondence to: Raissa Schwalbert

E-mail: raissa_schwalbert@hotmail.com

ORCid: https://orcid.org/0000-0002-8196-587X and this process leads to vineyard eradication. Soil organic matter (SOM) oxidation is increased by soil mobilization at vineyard replanting, besides increasing $\mathrm{Cu}$ availability in the soil (Campos et al. 2013), especially in soils presenting low physical SOM protection and low $\mathrm{Cu}$ sorption ability (Brunetto et al. 2014). It is known that $\mathrm{Cu}$ excess in soil is toxic to transplanted young vines in ancient vineyards (Miotto et al. 2014). 
$\mathrm{Cu}$ is an essential element for plants, but if its concentration in the soil is too high it can lead to $\mathrm{Cu}$ accumulation in plant tissue. Moreover, $\mathrm{Cu}$ excess causes negative plant response at physiological level and help inhibiting plant growth and development (Kabata-Pendias 2011). Cu excess can inhibit the flow of electrons in photosynthesis and change the composition of chloroplast membranes. Likewise, Cu excess can inhibit the synthesis of photosynthetic pigments such as chlorophylls and carotenoids and/ or change their structure (González-Mendoza et al. 2013, John et al. 2009).

$\mathrm{Cu}$ can also catalyze the production of reactive oxygen species (ROS), such as hydroxyl radical $(\mathrm{OH} \bullet$ ) formed in Fenton reactions (Gill and Tuteja 2010). ROS have one unpaired electron in their structures, thus they are highly reactive. Balance between ROS generation and elimination is controlled by the activity of antioxidant defense system (Becana et al. 2010). Oxidative stress is observed when the activity of antioxidant defense system is lower than the ROS production (Girotto et al. 2013). This phenomenon occurs because ROS damages the structures of fatty acids, such as lipid peroxidation in cell membranes, which, in turn, produce carbon compounds such as malondialdehyde (Soto et al. 2011). Thus, the balance between ROS production and antioxidant system activity is crucial for the survival and adaptation of plants growing in soils presenting high levels of heavy metals (Słomka et al. 2008). Superoxide dismutase (SOD) is the first defense line of the plant antioxidant system against ROS. These enzymes act in superoxide radical $\left(\mathrm{O}_{2}{ }^{\circ}\right)$ dismutation into less toxic forms such as $\mathrm{H}_{2} \mathrm{O}_{2}$ and $\mathrm{O}_{2}$ (Zouari et al. 2016). The SOD activity often increases under high concentration of metals such as $\mathrm{Cu}$ (Zhang et al. 2010).

Recent studies have been documented using cash crops on heavy metal phytoremediation on vineyards (Girotto et al. 2016, Marastoni et al. 2019, Tiecher et al. 2016a, b). The introduction of cash crops on this scenario has an additional benefit due to the financial return that can be obtained, besides promoting the maintenance of vegetal cover. Annual crops, such as soybean, can be cultivated for few years and become an alternative to $\mathrm{Cu}$ phytostabilization because it can make the future reinsertion of vines in previous soybean crop areas possible (Fellet et al. 2007, Murakami and Ae 2009, Pierzynski et al. 1994). Soybean is the most economically important grain legume in the global agricultural scenario (SánchezPardo et al. 2012). Furthermore, the inclusion of plants that symbiotically fix $\mathrm{N}_{2}$, such as soybean, can contribute to the ecosystem improvement by increasing the nitrogen available content in the soil, especially in vineyards soils that usually have low SOM content (Whiting et al. 2004, Conrad et al. 2018). However, studies on soybean tolerance to $\mathrm{Cu}$ excess in contaminated soils are still scarce, suggesting that room exists to further research on this topic (Silva et al. 2014).

The physiological responses of plants grown in soils presenting $\mathrm{Cu}$ excess can vary between species and/or between cultivars within a single species (Massocatto et al. 2013). Evaluating these responses can help uncovering strategies used by plants to uptake, accumulate and tolerate heavy metals. These responses also help detecting the cultivars that best adapt to $\mathrm{Cu}$ contaminated soils (Kabata-Pendias 2011, Cambrollé et al. 2013). The present study aimed to evaluate the physiological responses of different soybean cultivars to $\mathrm{Cu}$ excess. Therefore, we performed tissue composition, photosynthetic, biochemical, and growth measurements in plants cultivated under $\mathrm{Cu}$ increase concentrations in nutrient solution.

\section{MATERIALS AND METHODS}

\section{DESCRIPTION OF THE EXPERIMENT}

The study was carried out in a greenhouse located in Santa Maria, Rio Grande do Sul State, Southern 
Brazil $\left(29^{\circ} 42^{\prime} 56.44^{\prime \prime} S\right.$ and 53 $\left.3^{\circ} 3^{\prime} 12.57^{\prime} \mathrm{W}\right)$. Mean air temperature inside the greenhouse was set at $26{ }^{\circ} \mathrm{C}$ and relative humidity was $50 \%$. The experiment followed a completely randomized design, with 4 replicates.

The following soybean cultivars were assessed in the current study: NA 5909 RG (5909), DM 5958 RSF IPRO (5958), M 6410 IPRO (6410) and DM 6563 RSF IPRO (6563). According to the national register of cultivars (RNC, 2019), these cultivars were chosen, given their adaptability to climate and soil conditions in Southern Brazil (Embrapa 2014). Seeds were disinfested with $10 \%(\mathrm{v} / \mathrm{v})$ sodium hypochlorite for 15 minutes (Sánchez-Pardo et al. 2012), sown in moistened filter paper (2.5 times the weight of the dry paper) and stored in germinator type BOD (Box Organism Development) at $20^{\circ} \mathrm{C}$, under 24-h photoperiod.

Three seedlings of each soybean cultivar were transferred to plastic containers covered with polystyrene plates with holes, which were used as physical support for plants. Roots were immersed in an aerated full-nutrient solution expressed in $\mathrm{mg}$ $\mathrm{L}^{-1}: 85.31 \mathrm{~N} ; 7.54 \mathrm{P} ; 11.54 \mathrm{~S} ; 97.64 \mathrm{Ca} ; 23.68 \mathrm{Mg}$; $104.75 \mathrm{~K} ; 176.76 \mathrm{Cl} ; 0.27 \mathrm{~B} ; 0.05 \mathrm{Mo} ; 0.01 \mathrm{Ni}$; $0.13 \mathrm{Zn} ; 0.03 \mathrm{Cu} ; 0.11 \mathrm{Mn}$ and 2.68 Fe.

Three $\mathrm{Cu}$ concentrations $\left(\mathrm{CuSO}_{4}-0.5 \mu \mathrm{M}\right.$, which corresponds to the original concentration of the nutrient solution, 20 and $40 \mu \mathrm{M}$ ) were added to the nutrient solution after seven plant-acclimation days. Nutrient solution was replaced every four days during the experimental period - $\mathrm{pH}$ was adjusted to 5.5. Gas exchange evaluations were carried out and plants were collected 21 days after cultivation.

\section{DRY MATTER PRODUCTION AND TOTAL Cu} CONCENTRATION IN PLANT TISSUES

Two plants from each replicate were harvested and roots and shoots were divided. The roots were washed and dried with absorbent paper and reserved. Root and shoot samples were dried in forced air-circulation oven at $\pm 65^{\circ} \mathrm{C}$, until they reached constant mass. Root (MSR) and shoot dry masses (MSPA) were measured in precision scale (Shimadzu, AY220, Philippines). Root and shoot samples were ground in Wiley mill after drying and passed through $2 \mathrm{~mm}$ mesh sieve. $0.25 \mathrm{~g}$ of plant tissue was subjected to nitroperchloric digestion (3.0 $\mathrm{mL}$ of $\mathrm{HNO}_{3} 65 \%$ P.A and $1 \mathrm{~mL}$ of $\mathrm{HClO}_{4} 70 \%$ P.A.) (Embrapa 2009). Total $\mathrm{Cu}$ concentration was analyzed in atomic absorption spectrophotometer (AAS, Perkin Elmer Analyst 200, USA).

\section{GAS EXCHANGES}

Gas exchanges were measured 21 days after transplantation (DAT) in Infrared Gas Analyzer (IRGA- Li-COR ${ }^{\circledR} 6400$ XT, Lincoln, NE, EUA). Measurements were performed between 8:00 and 10:00 a.m. at $\mathrm{CO}_{2}$ concentration $400 \mu \mathrm{mol} \mathrm{mol}^{-1}$ and photon flux density $1500 \mu \mathrm{mol} \mathrm{m} \mathrm{m}^{-2} \mathrm{~s}^{-1}$. One plant from each replicate was selected and the last fully expanded trifoliolated leaf was used to measure gas exchange. The following parameters were observed: net photosynthetic rate (A), intercellular $\mathrm{CO}_{2}$ concentration $\left(\mathrm{C}_{\mathrm{i}}\right)$, transpiration rate $(\mathrm{E})$, stomatal conductance $\left(\mathrm{G}_{\mathrm{s}}\right)$, water-use efficiency (WUE) and RuBisCo instantaneous carboxylation efficiency $\left(\mathrm{A} / \mathrm{C}_{\mathrm{i}}\right)$. WUE was the ratio between the amount of $\mathrm{CO}_{2}$ fixed through photosynthesis and the amount of transpired water. $\mathrm{A} / \mathrm{C}_{\mathrm{i}}$ was the ratio between the amount of $\mathrm{CO}_{2}$ fixed through photosynthesis and the intercellular $\mathrm{CO}_{2}$ concentration.

The leaves and roots of each plant were collected immediately after the end of the measurements and frozen in liquid nitrogen. Samples were macerated in liquid nitrogen to determine photosynthetic pigments, SOD activity, $\mathrm{H}_{2} \mathrm{O}_{2}$ concentration and lipid peroxidation.

\section{EXTRACTION AND QUANTIFICATION OF} PHOTOSYNTHETIC PIGMENTS

The concentration of photosynthetic pigments was determined based on the methodology 
proposed by Hiscox and Israelstam (1979), by using Lichtenthaler (1987) formulae. $0.05 \mathrm{~g}$ of plant material were weighed and, then, incubated for $5 \mathrm{~min}$ at $65{ }^{\circ} \mathrm{C}$ in $40 \mathrm{~mL}$ of dimethylsulfoxide (DMSO) until the pigments were fully removed from the assessed tissues. Supernatant solution absorbance was determined in spectrophotometer (Bel Photonics, 1105, Brazil) at wavelengths 663, 645 and $470 \mathrm{~nm}$ in order to determine chlorophyll a, b, and carotenoids, respectively. Total chlorophyll results from the sum of chlorophyll a and $b$ values.

\section{SOD ACTIVITY}

Half gram of plant material was homogenized in $3 \mathrm{~mL}$ of sodium phosphate buffer solution $(0.05$ mol $\mathrm{L}^{-1}$ ) at $\mathrm{pH} 7.8$, including $1 \mathrm{mM}$ EDTA and $0.5 \%$ Triton $\mathrm{X}-100$. The homogenate extract was centrifuged at $13000 \mathrm{~g}$ for $20 \mathrm{~min}$ at $4{ }^{\circ} \mathrm{C}$. Enzymatic activity and protein content were determined by using the supernatant (Bradford 1976, Zhu et al. 2004).

SOD activity was determined based on the spectrophotometric method described by Giannopolitis and Ries (1977). $3 \mathrm{~mL}$ of a mixture containing $50 \mathrm{mM}$ of potassium phosphate buffer (pH 7.8), methionine (13 mM), EDTA $(0.1 \mu \mathrm{M})$, NBT $(75 \mu \mathrm{M})$ and riboflavin $(2 \mu \mathrm{M})$ were added to the tubes, which were incubated under fluorescent lamps (15 watts) for $15 \mathrm{~min}$. Absorbance was determined in spectrophotometer (Bel Photonics, 1105, Brazil) at wavelength $560 \mathrm{~nm}$. NBT ( $\rho$-nitro blue tetrazolium) reduction inhibition by enzymatic extract was determined based on this spectrophotometric method. Extract-free tubes exposed, or not, to light were used as blanks for the reaction. The SOD enzymatic activity unit (U) was defined as the amount of enzyme required to find 50\% NBT reduction inhibition through SOD, which was observed in the enzyme extract. SOD activity was determined by calculating the amount of extract inhibiting 50\% NBT reaction and was expressed as $\mathrm{U} \mathrm{mg}^{-1}$ protein.

HYDROGEN PEROXIDE $\left(\mathrm{H}_{2} \mathrm{O}_{2}\right)$

$\mathrm{H}_{2} \mathrm{O}_{2}$ concentration was determined based on the methodology by Loreto and Velikova (2001). Therefore, $0.1 \mathrm{~g}$ of plant material was homogenized in $2.0 \mathrm{~mL}$ of $0.1 \%(\mathrm{w} / \mathrm{v})$ trichloroacetic acid (TCA) and, subsequently, centrifuged at $12000 \mathrm{~g}$ for 15 min at $4{ }^{\circ} \mathrm{C} .0 .5 \mathrm{~mL}$ of supernatant was added with $0.5 \mathrm{~mL}$ of potassium phosphate buffer $(10 \mathrm{mM})(\mathrm{pH}$ $7.0)$ and $1 \mathrm{~mL}$ of $\mathrm{KI}\left(1 \mathrm{~mol} \mathrm{~L}^{-1}\right)$. Absorbance was determined in spectrophotometer (Bel Photonics, 1105 , Brazil) at wavelength $390 \mathrm{~nm}$.

\section{LIPID PEROXIDATION}

Thiobarbituric acid reactive substances (TBARS) were determined based on the methodology by El-Moshaty et al. (1993), which quantifies malondialdehyde (MDA) accumulation as the result from lipid peroxidation. Half gram of plant material was added with $4.0 \mathrm{~mL}$ of citrate phosphate buffer TFK 0.2 M (pH 6.5). Samples were centrifuged in refrigerated centrifuge at $4{ }^{\circ} \mathrm{C}$ for $15 \mathrm{~min}$ at $20000 \mathrm{~g}$.

Aliquots of $1.5 \mathrm{~mL}$ of supernatant were collected for TBARS determination. The same volume of thiobarbituric acid (TBA) $-0.5 \%(\mathrm{w} / \mathrm{v})$ - and trichloroacetic acid (TCA) - 20\% (w/v) - was added to the samples; which were incubated in water bath at $95{ }^{\circ} \mathrm{C}$ for $40 \mathrm{~min}$. The reaction was stopped in ice bath for $15 \mathrm{~min}$ and samples were centrifuged at $10000 \mathrm{~g}$ for $5 \mathrm{~min}$. Absorbance was determined in spectrophotometer (Bel Photonics, 1105 , Brazil) at $532 \mathrm{~nm}$, by subtracting the nonspecific absorbance at $600 \mathrm{~nm}$.

\section{STATISTICAL ANALYSIS}

Residue normality was subjected to Shapiro-Wilk test. Different homocedastic and heterocedastic models were selected based on the Akaike 
information criterion (AIC) and Bayesian information criterion (BIC). All models were adjusted in the "nlme" package (Pinheiro et al. 2017) of the R statistical environment (R Core Team 2017). Results were subjected to analysis of variance and tested through F test. Means were compared through Scott Knott test, at 5\% error probability. The principal component analysis (PCA) was performed to assess correlation structure and the degree of association between different variables that were taken into consideration in the current study. PCA allowed identifying more complex associations between the evaluated variables and the identification of variables responsible for the greatest contributions to differences between treatments. Only components presenting eigenvalue higher than 1 were taken into account in the present study. The principal component analysis was performed in "FactoMineR" (Lê et al. 2008), which is a package of the $\mathrm{R}$ statistical environment (R Core Team 2017).

\section{RESULTS}

\section{DRY MATTER PRODUCTION AND TOTAL Cu} CONCENTRATION IN PLANT TISSUE

All soybean cultivars tested in the current study recorded decreased shoot dry mass (SDM) production as $\mathrm{Cu}$ concentration in the nutrient solution increased (Table I); however, SDM production did not differ between cultivars. Cultivar 5958 (grown at $\mathrm{Cu}$ concentrations 20 and $40 \mu \mathrm{M}$ ) presented $24 \%$ and $45 \%$ root dry mass (RDM) decrease, respectively, in comparison to the control concentration $(0.5 \mu \mathrm{M} \mathrm{Cu})$.

The RDM/SDM ratio in this cultivar did not differ between $\mathrm{Cu}$ concentrations; this outcome evidences that the $\mathrm{Cu}$ excess had similar effect on shoots and roots. $\mathrm{Cu}$ concentrations did not affect RDM production in cultivars 6410 and 6563 . $\mathrm{RDM} / \mathrm{SDM}$ ratio was $55 \%$ higher in these cultivars grown at $\mathrm{Cu}$ concentration $40 \mu \mathrm{M}$ than in the $\mathrm{Cu}$ control concentration (Table I).

$\mathrm{Cu}$ concentrations in shoot and root tissues increased in all soybean cultivars as $\mathrm{Cu}$ concentration in the nutrient solution also increased (Figure 1). $\mathrm{Cu}$ concentration in shoot and root tissues did not differ between cultivars at $\mathrm{Cu}$ control concentration $(0.5 \mu \mathrm{M})$. Cultivar 6563 recorded the highest $\mathrm{Cu}$ concentration in plant shoots at $\mathrm{Cu}$ concentration $20 \mu \mathrm{M}$. Cu concentration in the roots did not statistically differ between cultivars in this treatment. Cultivar 5909 presented the highest $\mathrm{Cu}$ concentration in the shoots of plants grown at $\mathrm{Cu}$ concentration $40 \mu \mathrm{M}$, approximately 10 times higher than that observed in the control concentration. Besides, cultivar 5909 presented the

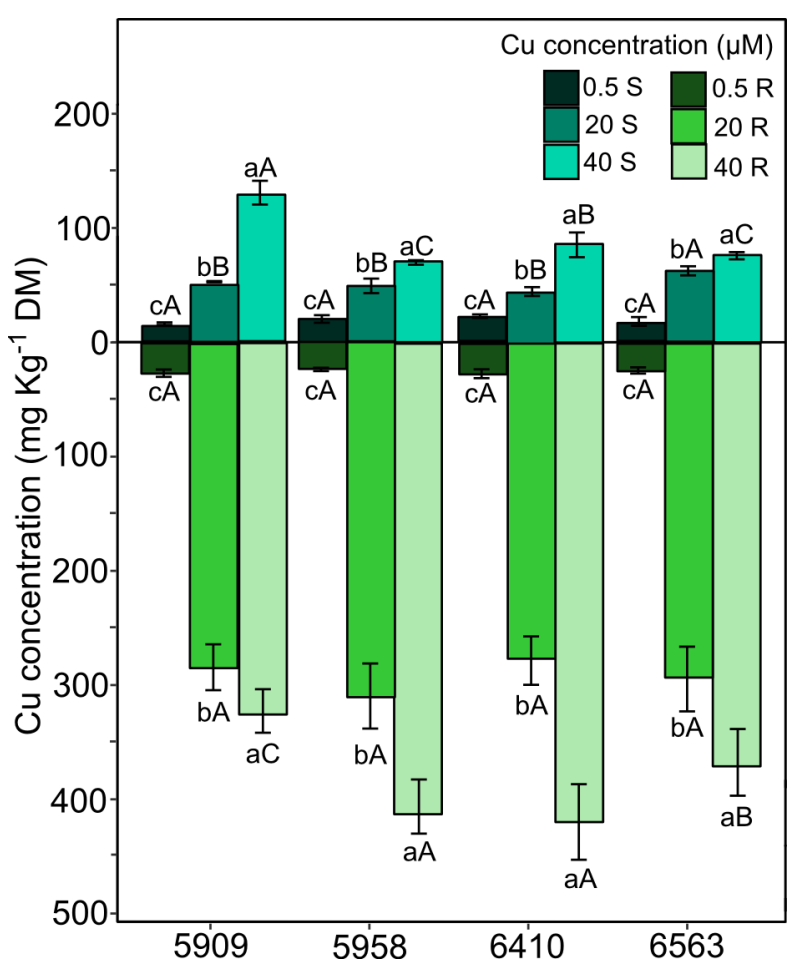

Figure 1 - $\mathrm{Cu}$ concentration in the shoots $(\mathrm{S})$ and roots $(\mathrm{R})$ of four soybean cultivars $(5909,5958,6410$ and 6563) grown in nutrient solution at three $\mathrm{Cu}$ concentrations $(0.5,20$ and 40 $\mu \mathrm{M})$. Capital letters indicate comparison between cultivars in the same $\mathrm{Cu}$ concentration and plant part. Lowercase letters indicate comparisons between $\mathrm{Cu}$ concentrations in the same cultivar and plant part $(\mathrm{p}<0.05)$. Vertical bars represent \pm standard deviation. 
TABLE I

Root dry mass, root dry mass/ shoot dry mass ratio and shoot dry mass of four soybean cultivars $(5909,5958,6410$ and 6563) grown in nutrient solution at three $C u$ concentrations $(0.5,20$ and $40 \mu M)$.

\begin{tabular}{|c|c|c|c|c|}
\hline \multirow{2}{*}{$\begin{array}{l}\text { Cu concentration } \\
(\mu \mathrm{M})\end{array}$} & \multicolumn{4}{|c|}{ Root dry mass (g)* } \\
\hline & 5909 & 5958 & 6410 & 6563 \\
\hline 0.5 & $0.22 \pm 0.01 \mathrm{aC}$ & $0.37 \pm 0.03 \mathrm{aA}$ & $0.27 \pm 0.03 \mathrm{aB}$ & $0.25 \pm 0.03 \mathrm{aB}$ \\
\hline 20 & $0.24 \pm 0.04 \mathrm{aB}$ & $0.28 \pm 0.02 \mathrm{bA}$ & $0.24 \pm 0.00 \mathrm{aB}$ & $0.27 \pm 0.02 \mathrm{aA}$ \\
\hline 40 & $0.14 \pm 0.01 \mathrm{bC}$ & $0.20 \pm 0.01 \mathrm{cB}$ & $0.24 \pm 0.01 \mathrm{aA}$ & $0.27 \pm 0.02 \mathrm{aA}$ \\
\hline \multirow{2}{*}{$\begin{array}{c}\text { Cu concentration } \\
(\mu \mathrm{M})\end{array}$} & \multicolumn{4}{|c|}{ Root dry mass/shoot dry mass ratio (g) } \\
\hline & 5909 & 5958 & 6410 & 6563 \\
\hline 0.5 & $0.11 \pm 0.01 \mathrm{bC}$ & $0.17 \pm 0.02 \mathrm{aA}$ & $0.14 \pm 0.01 \mathrm{bB}$ & $0.12 \pm 0.01 \mathrm{cC}$ \\
\hline 20 & $0.14 \pm 0.02 \mathrm{aB}$ & $0.16 \pm 0.02 \mathrm{aA}$ & $0.13 \pm 0.01 \mathrm{bB}$ & $0.15 \pm 0.01 \mathrm{bB}$ \\
\hline 40 & $0.11 \pm 0.01 \mathrm{bC}$ & $0.19 \pm 0.02 \mathrm{aB}$ & $0.21 \pm 0.03 \mathrm{aA}$ & $0.18 \pm 0.02 \mathrm{aB}$ \\
\hline \multirow{2}{*}{$\begin{array}{c}\text { Cu concentration } \\
(\mu \mathrm{M})\end{array}$} & \multicolumn{4}{|c|}{ Shoot dry mass $(g)^{*}$} \\
\hline & 5909 & 5958 & 6410 & 6563 \\
\hline 0.5 & $2.03 \pm 0.17 \mathrm{a}$ & $2.15 \pm 0.36 \mathrm{a}$ & $1.98 \pm 0.12 \mathrm{a}$ & $2.12 \pm 0.22 \mathrm{a}$ \\
\hline 20 & $1.77 \pm 0.25 \mathrm{~b}$ & $1.67 \pm 0.13 \mathrm{~b}$ & $1.80 \pm 0.17 \mathrm{~b}$ & $1.80 \pm 0.08 \mathrm{~b}$ \\
\hline 40 & $1.34 \pm 0.06 \mathrm{c}$ & $1.10 \pm 0.08 \mathrm{c}$ & $1.13 \pm 0.10 \mathrm{c}$ & $1.47 \pm 0.08 \mathrm{c}$ \\
\hline
\end{tabular}

Values from two plants. ${ }^{*}$ Values represent the means \pm standard deviation of four repetitions. Capital letters indicate comparison between cultivars in the same $\mathrm{Cu}$ concentration, whereas lowercase letters indicate a comparison between $\mathrm{Cu}$ concentrations in the same cultivar $(\mathrm{p}<0.05)$.

lowest $\mathrm{Cu}$ concentration in the roots. Cultivars 5958 and 6410 recorded the highest $\mathrm{Cu}$ concentrations in the roots of plants grown at $\mathrm{Cu}$ concentration 40 $\mu \mathrm{M}$ (Figure 1).

\section{GAS EXCHANGES}

$\mathrm{Cu}$ excess in the nutrient solution changed the photosynthetic parameters of soybean cultivars. Cultivar 6563 was the only one presenting lower net photosynthetic rate (A) at $\mathrm{Cu}$ concentration $20 \mu \mathrm{M}$ than that observed in the control treatment (Figure 2a). The other three cultivars presented the highest $\mathrm{A}$ and $\mathrm{A} / \mathrm{Ci}$ values at $\mathrm{Cu}$ concentration $20 \mu \mathrm{M}$ (Figures $2 \mathrm{a}, \mathrm{b}$ ). Intercellular $\mathrm{CO}_{2}$ concentration $\left(\mathrm{C}_{\mathrm{i}}\right)$ and transpiration rate $(\mathrm{E})$ decreased in all cultivars subjected to the aforementioned $\mathrm{Cu}$ concentration (Figures 2c, d). Except for cultivar 6410, whose plants did not differ from the control treatment in this variable, the same result was observed for stomatal conductance $\left(\mathrm{G}_{\mathrm{s}}\right)$ (Figure $2 \mathrm{e}$ ).
All soybean cultivars grown at $\mathrm{Cu}$ concentration $40 \mu \mathrm{M}$ presented the lowest $\mathrm{A}, \mathrm{A} / \mathrm{Ci}, \mathrm{Ci}, \mathrm{E}$ and $\mathrm{G}_{\mathrm{s}}$ values, which were compared to values observed at different $\mathrm{Cu}$ concentrations. However, cultivar 6410 was less sensitive to $\mathrm{Cu}$ excess, since it showed $70 \% \mathrm{~A}$ in the control (Figure 2). On the other hand, cultivar 5958 was the most sensitive to $\mathrm{Cu}$ concentration $40 \mu \mathrm{M}$, since it maintained only $23 \% \mathrm{~A}$ in the control.

Water use efficiency (WUE) was lower in all soybean cultivars grown at $\mathrm{Cu}$ control concentration in comparison to other concentrations. There was no variation in WUE at $\mathrm{Cu}$ concentrations 20 or 40 $\mu \mathrm{M}$ in all cultivars, except for cultivar 6410 , which showed maximum WUE at $20 \mu \mathrm{M}$ of $\mathrm{Cu}$ (Figure 2f).

\section{PHOTOSYNTHETIC PIGMENTS}

All soybean cultivars grown at $\mathrm{Cu}$ concentration 40 $\mu \mathrm{M}$ presented lower concentration of photosynthetic pigments than the other $\mathrm{Cu}$ concentrations (Table 

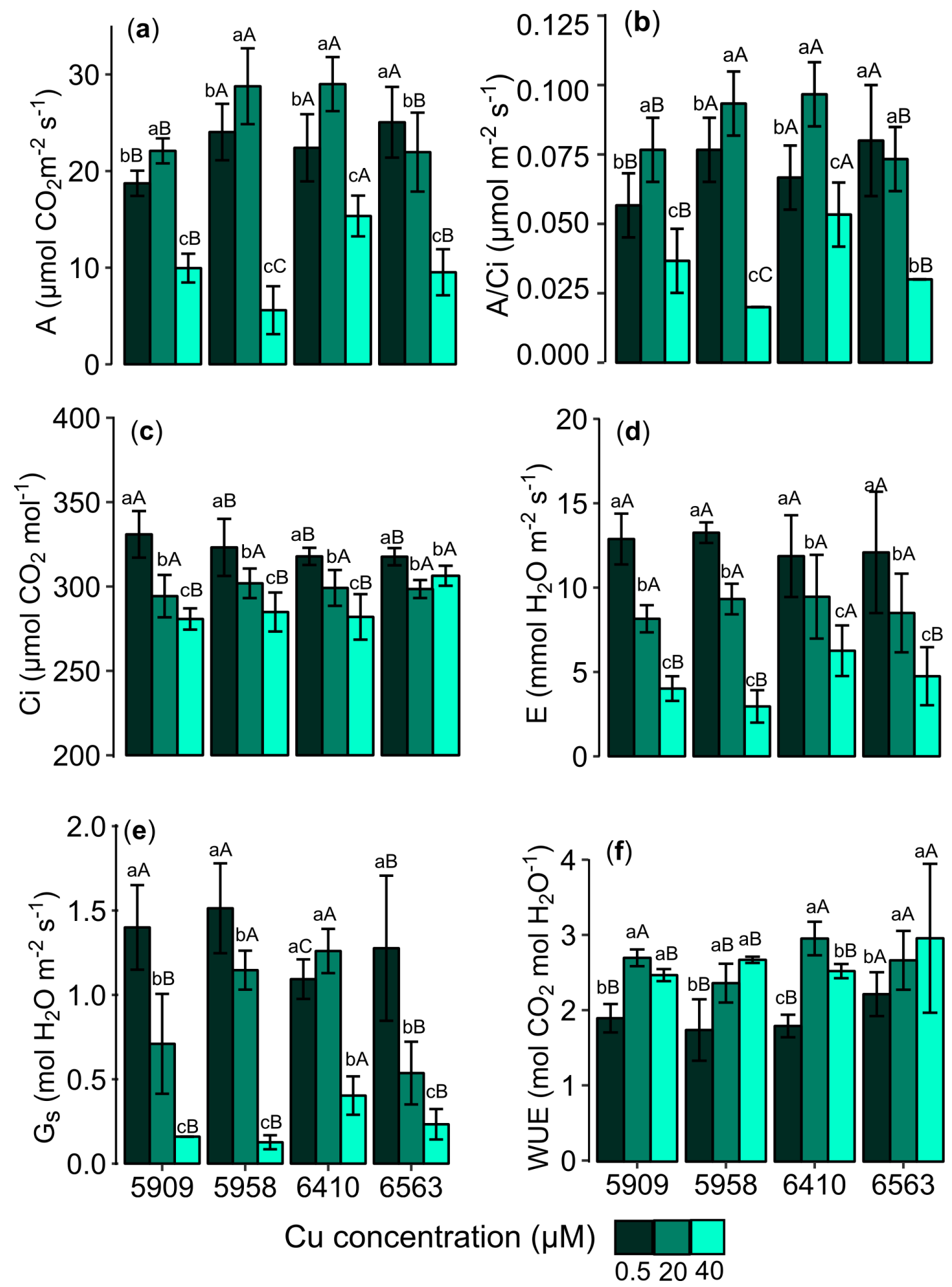

Figure 2 - Net photosynthetic rate (a), RuBisCo instantaneous carboxylation efficiency (b), intercellular $\mathrm{CO}_{2}$ concentration (c), transpiration rate (d), stomatal conductance (e) and water use efficiency (f) of four soybean cultivars $(5909,5958,6410$ and 6563) grown in nutrient solution at three different $\mathrm{Cu}$ concentrations $(0.5,20$ and $40 \mu \mathrm{M})$. Capital letters indicate comparison between cultivars in the same $\mathrm{Cu}$ concentration. Lowercase letters indicate comparison between $\mathrm{Cu}$ concentrations in the same cultivar $(\mathrm{p}<0.05)$. Vertical bars represent \pm standard deviation. 
II). Cultivars 6410 and 5958 showed chlorophyll concentration increase at $\mathrm{Cu}$ concentration 20 $\mu \mathrm{M}$, and cultivar 5958 recorded chlorophyll b concentration and total chlorophyll increase (Table II).

\section{SOD ACTIVITY}

The lowest SOD activity in plant roots and shoots, in all soybean cultivars, was recorded for plants grown at low $\mathrm{Cu}$ concentration $(0.5 \mu \mathrm{M})$. SOD activity in plant roots and shoots increased at $\mathrm{Cu}$ concentrations 20 or $40 \mu \mathrm{M}$ in the nutrient solution. SOD activity was often higher in the shoots than in the roots; SOD activity in the roots was similar in soybean cultivars at $\mathrm{Cu}$ concentrations 0.5 and $20 \mu \mathrm{M}$. However, cultivar 6410 showed the highest SOD activity in the roots of plants cultivated at $\mathrm{Cu}$ concentration 40 $\mu \mathrm{M}$ than in other cultivars (Figure 3a).
HYDROGEN PEROXIDE $\left(\mathrm{H}_{2} \mathrm{O}_{2}\right)$

$\mathrm{H}_{2} \mathrm{O}_{2}$ concentration in the shoots and roots was similar in all soybean cultivars grown at $\mathrm{Cu}$ concentration $0.5 \mu \mathrm{M} . \mathrm{H}_{2} \mathrm{O}_{2}$ concentrations in the roots and shoots of all cultivars grown at $\mathrm{Cu}$ concentration $40 \mu \mathrm{M}$ were often higher than the control. Cultivar 5909 presented the highest $\mathrm{H}_{2} \mathrm{O}_{2}$ concentration in the shoots at the aforementioned $\mathrm{Cu}$ concentration in nutrient solution. Likewise, cultivars 6563 and 5958 presented the highest and the lowest $\mathrm{H}_{2} \mathrm{O}_{2}$ concentrations in the roots, respectively (Figure $3 b$ ).

\section{LIPID PEROXIDATION}

Malondialdehyde (MDA) concentrations in the shoots showed differences in cultivar 6563 , which recorded MDA level increase by $45 \%$ when plants were cultivated at $\mathrm{Cu}$ concentration

TABLE II

Chlorophyll and carotenoid concentration in the leaves of the four soybean cultivars $(5909,5958,6410$ and 6563$)$ grown in nutrient solution at $\mathrm{Cu}$ concentrations: $0.5,20$ and $40 \mu \mathrm{M}$.

\begin{tabular}{|c|c|c|c|c|}
\hline Cu concentration $(\mu \mathrm{M})$ & 5909 & 5958 & 6410 & 6563 \\
\hline \multicolumn{5}{|c|}{ Chlorophyll a $\left(\mathrm{mg} \mathrm{g}^{-1} \mathrm{FW}\right)$} \\
\hline 0.5 & $1.20 \pm 0.12 \mathrm{aA}^{*}$ & $1.09 \pm 0.16 \mathrm{bB}$ & $1.03 \pm 0.01 \mathrm{bB}$ & $1.05 \pm 0.03 \mathrm{aB}$ \\
\hline 20 & $1.04 \pm 0.11 \mathrm{bB}$ & $1.34 \pm 0.05 \mathrm{aA}$ & $1.04 \pm 0.02 \mathrm{aB}$ & $1.16 \pm 0.11 \mathrm{aB}$ \\
\hline 40 & $0.78 \pm 0.05 \mathrm{cA}$ & $0.67 \pm 0.03 \mathrm{cA}$ & $0.46 \pm 0.06 \mathrm{cB}$ & $0.59 \pm 0.05 \mathrm{bB}$ \\
\hline \multicolumn{5}{|c|}{ Chlorophyll b (mg g $\left.g^{-1} F W\right)$} \\
\hline 0.5 & $0.36 \pm 0.04 \mathrm{aA}$ & $0.33 \pm 0.03 \mathrm{bA}$ & $0.29 \pm 0.02 \mathrm{aB}$ & $0.29 \pm 0.01 \mathrm{aB}$ \\
\hline 20 & $0.28 \pm 0.03 \mathrm{bC}$ & $0.40 \pm 0.02 \mathrm{aA}$ & $0.26 \pm 0.01 \mathrm{aC}$ & $0.32 \pm 0.04 \mathrm{aB}$ \\
\hline 40 & $0.21 \pm 0.03 \mathrm{cA}$ & $0.18 \pm 0.02 \mathrm{cA}$ & $0.11 \pm 0.02 \mathrm{bB}$ & $0.15 \pm 0.01 \mathrm{bB}$ \\
\hline \multicolumn{5}{|c|}{ Total chlorophyll (mg $\left.g^{-1} \mathrm{FW}\right)$} \\
\hline 0.5 & $1.56 \pm 0.03 \mathrm{aA}$ & $1.42 \pm 0.02 \mathrm{bB}$ & $1.32 \pm 0.02 \mathrm{aB}$ & $1.34 \pm 0.01 \mathrm{aB}$ \\
\hline 20 & $1.32 \pm 0.01 \mathrm{bC}$ & $1.75 \pm 0.01 \mathrm{aA}$ & $1.30 \pm 0.01 \mathrm{aC}$ & $1.49 \pm 0.01 \mathrm{aB}$ \\
\hline 40 & $0.99 \pm 0.01 \mathrm{cA}$ & $0.86 \pm 0.03 \mathrm{cA}$ & $0.58 \pm 0.03 \mathrm{bB}$ & $0.74 \pm 0.01 \mathrm{bB}$ \\
\hline \multicolumn{5}{|c|}{ Carotenoids (mg $\left.g^{-1} F W\right)$} \\
\hline 0.5 & $0.33 \pm 0.16 \mathrm{aA}$ & $0.35 \pm 0.17 \mathrm{aA}$ & $0.28 \pm 0.01 \mathrm{aB}$ & $0.31 \pm 0.05 \mathrm{aB}$ \\
\hline 20 & $0.29 \pm 0.14 \mathrm{bC}$ & $0.37 \pm 0.07 \mathrm{aA}$ & $0.26 \pm 0.03 \mathrm{aD}$ & $0.33 \pm 0.15 \mathrm{aB}$ \\
\hline 40 & $0.21 \pm 0.07 \mathrm{cA}$ & $0.19 \pm 0.05 \mathrm{bA}$ & $0.12 \pm 0.06 \mathrm{bC}$ & $0.16 \pm 0.06 \mathrm{bB}$ \\
\hline
\end{tabular}

*Values represent means \pm standard deviation of the four repetitions. Capital letters indicate comparison between cultivars at the same $\mathrm{Cu}$ concentration. Lowercase letters indicate comparison between $\mathrm{Cu}$ concentrations in the same cultivar $(\mathrm{p}<0.05)$. 

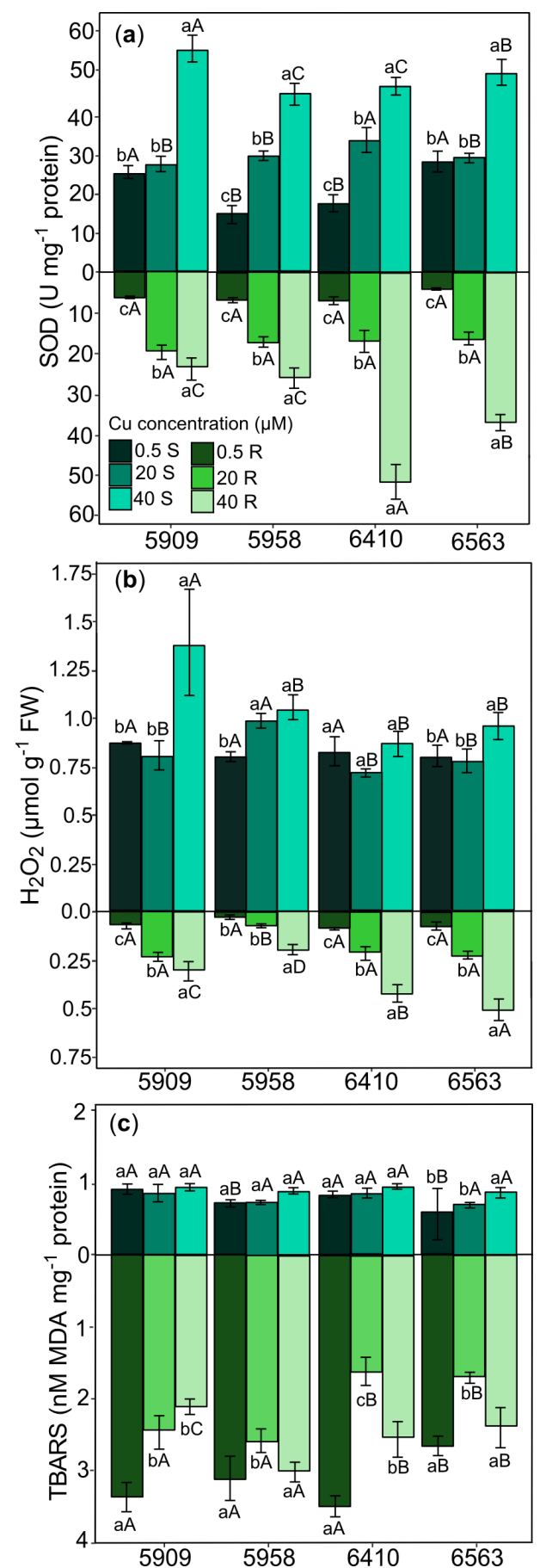

Figure 3 - Enzymatic activity of superoxide dismutase (a), hydrogen peroxide concentration (b) and malondialdehyde concentration (c) of four soybean cultivars $(5909,5958,6410$ and 6563) grown in nutrient solution at three different $\mathrm{Cu}$ concentrations $(0.5,20$ and $40 \mu \mathrm{M})$. Capital letters indicate comparison between cultivars in the same $\mathrm{Cu}$ concentration. Lowercase letters indicate comparison between $\mathrm{Cu}$ concentrations in the same cultivar $(\mathrm{p}<0.05)$. Vertical bars represent \pm standard deviation.
$40 \mu \mathrm{M}$ in comparison to the control. The roots of plants grown at $\mathrm{Cu}$ concentration $20 \mu \mathrm{M}$ recorded decreased MDA concentrations in comparison to the control (Figure 3c).

\section{PRINCIPAL COMPONENT ANALYSIS}

According to the eigenvalue threshold $(>1)$, only the two first components were retained, and it explains the $78.84 \%$ variation in the original results (Figure $4 \mathrm{a}$ ). Of this total, $66.46 \%$ variation was explained by principal component 1 (PC 1) and $12.38 \%$ was justified by principal component 2 (PC 2). PC 1 separated $\mathrm{Cu}$ concentrations 0.5 and $20 \mu \mathrm{M}$ from the treatment at $\mathrm{Cu}$ concentration 40 $\mu \mathrm{M}$. The most influent variables in the group at $\mathrm{Cu}$ concentrations 0.5 and $20 \mu \mathrm{M}$ in this separation were photosynthetic pigment concentrations, photosynthetic variables (except for WUE), dry mass and MDA concentration in the roots. Variables in the group subjected to the highest $\mathrm{Cu}$ concentration, that have mostly contributed to this separation were $\mathrm{Cu}$ concentration in plant tissue, SOD activity and $\mathrm{H}_{2} \mathrm{O}_{2}$ concentration in the roots and shoots, MDA concentration in shoots and WUE (Figure 4).

\section{DISCUSSION}

$\mathrm{Cu}$ concentrations observed in soybean plants grown at $\mathrm{Cu}$ concentration $40 \mu \mathrm{M}$ can be toxic (KabataPendias 2011); moreover, they showed negative correlation to dry mass production (Figure 4). The lower SDM observed at $\mathrm{Cu}$ concentration $40 \mu \mathrm{M}$ (Table I) can be attributed to lower photosynthesis (A) (Figure 2a), which was also suggested by Cambrollé et al. (2013). This may occur because the high $\mathrm{Cu}$ concentration in the shoots can cause disorders in photosynthetic processes (Zhang et al. 2014) by (i) preventing the flow of electrons in the photochemical phase of the photosynthesis, (ii) by altering the composition of thylakoid membranes and of photosynthetic pigments, and (iii) by 


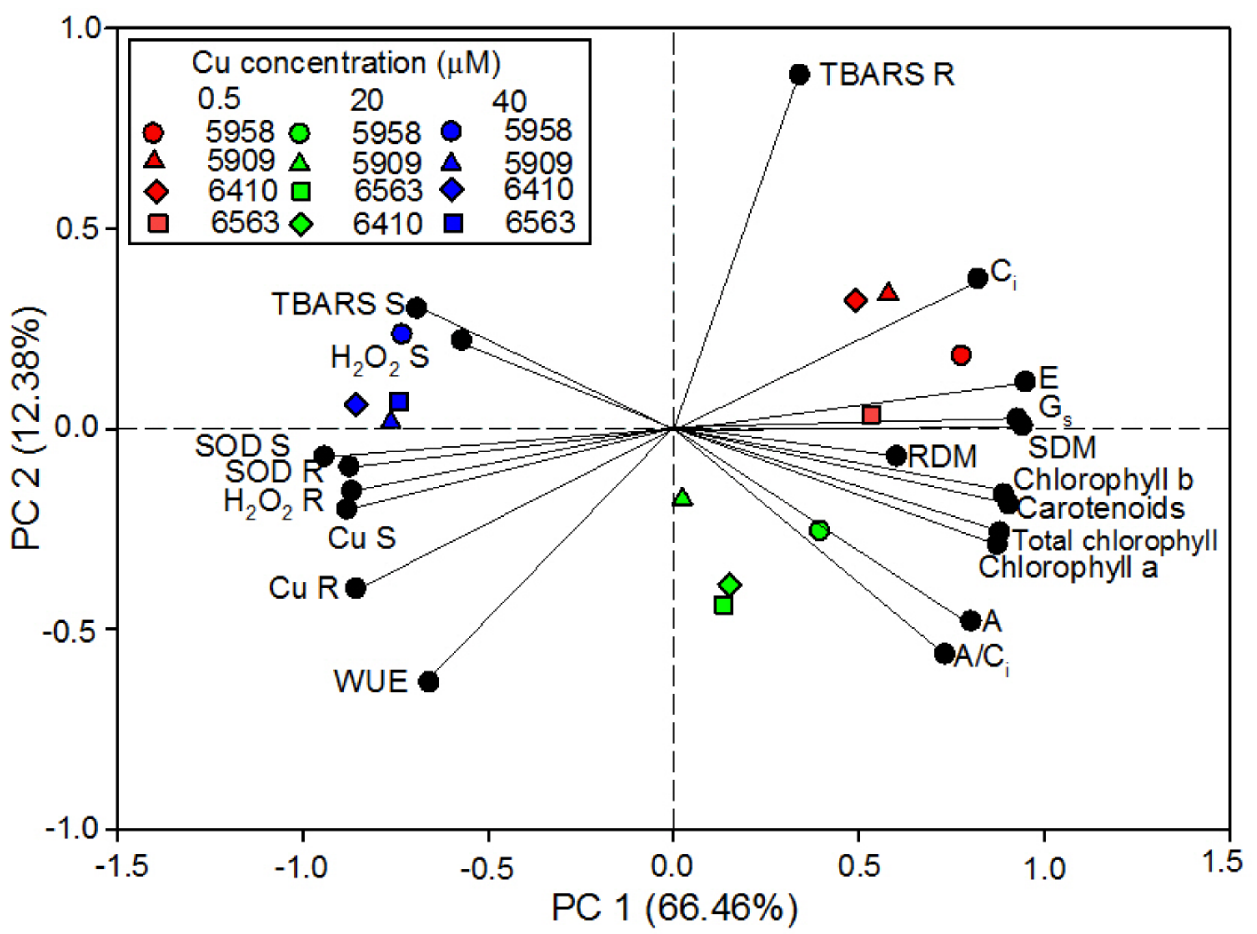

Figure 4 - Relationship between principal component 1 (PC1) and principal component 2 (PC2) in the variables such as groups of photosynthetic parameters $\left(A, A / C_{i}, C_{i}, E, G_{s}\right.$ and WUE), photosynthetic pigments (chlorophyll a, chlorophyll b, total chlorophyll and carotenoids) shoot dry mass (SDM), root dry mass (RDM), $\mathrm{Cu}$ concentration in shoots and roots ( $\mathrm{Cu} \mathrm{S}$ and $\mathrm{Cu} \mathrm{R}$ ), enzymatic activity of superoxide dismutase in shoots and roots (SOD S and SOD R), hydrogen peroxide concentration in shoots and roots $\left(\mathrm{H}_{2} \mathrm{O}_{2} \mathrm{~S}\right.$ and $\left.\mathrm{H}_{2} \mathrm{O}_{2} \mathrm{R}\right)$ and lipid peroxidation in shoots and roots (TBARS S and TBARS R) in the four soybean cultivars $(5909,5958,6410$ and 6563) subjected to different $\mathrm{Cu}$ concentrations in nutrient solution $(0.5,20$ and $40 \mu \mathrm{M})$.

inhibiting the synthesis or activity of Calvin cycle enzymes (John et al. 2009, González-Mendoza et al. 2013).

SDM production decrease in cultivars 5958, 5909 and 6410 observed at $\mathrm{Cu}$ concentration 20 $\mu \mathrm{M}$ did not affect the photosynthetic rate of these cultivars. Such outcome can be related to the adoption of some tolerance mechanisms triggered by plants, which have used photosynthetic products instead of growth (Bazihizina et al. 2015). Such tolerance mechanisms to $\mathrm{Cu}$ excess can be the synthesis of metal binders to sequester excess $\mathrm{Cu}$ in cell cytoplasm and/or metal compartmentalization in the vacuole (Hall 2002). In addition, the generation of reactive oxygen species (ROS) can be responsible for the decrease in dry biomass in soybean plants, because of the negative correlation between $\mathrm{H}_{2} \mathrm{O}_{2}$ concentration and dry mass production (SDM and RDM) (Figure 4). This process is based on the principle that organisms can mobilize their energy reserves to withstand stress conditions, such as the detoxification process influencing costs with biological functions such as growth (Calow 1991).

$\mathrm{Cu}$ concentration in plant tissues increased, as metal concentration in the nutrient solution also increased (Figure 1), but it was higher in plant roots than in shoots. This behavior derives from $\mathrm{Cu}$ immobilization due to extracellular carbohydrates in the cell wall of roots. This process allows less ions to remain free in the cytoplasm and to be carried to the shoots (Lasat 2002). This restriction in $\mathrm{Cu}$ translocation to the shoots seems to be a survival strategy adopted by plants, which seek to 
maintain lower concentration of metals in their most photosynthetic-sensitive organs. $\mathrm{Cu}$ accumulation is higher in the least sensitive organs, such as the roots (Yang et al. 2011); cultivars 6563 and 6410 showed greater ability to accumulate $\mathrm{Cu}$ in their roots (Figure 1), without leading to decrease on RDM production (Table I). On the other hand, these cultivars recorded decrease on SDM production when plants were grown in medium presenting $\mathrm{Cu}$ excess (Table I). This outcome resulted in MSR/ MSPA ratio increase due to $\mathrm{Cu}$ excess. According to Zhang et al. (2014), this MSR/MSPA ratio increase can be a mechanism to improve the uptake of other nutrients, or of some other limiting resources affected by high $\mathrm{Cu}$ concentrations.

$\mathrm{Cu}$ concentration $20 \mu \mathrm{M}$ increased the net photosynthetic rate (A) and RuBisCo instantaneous carboxylation efficiency $\left(\mathrm{A} / \mathrm{C}_{\mathrm{i}}\right)$ of cultivars 5909 , 5958 and 6410 . This result was observed, although there was small restriction in stomatal conductance $\left(\mathrm{G}_{\mathrm{s}}\right)$ and decrease in intercellular $\mathrm{CO}_{2}$ concentration $\left(\mathrm{C}_{\mathrm{i}}\right)$ (Figure 1). $\mathrm{Cu}$ is a structural component of plastocyanin, which plays a key role in the transportation of the electron chain in photosynthesis (Yruela 2013) this outcome helps explaining the A and $\mathrm{A} / \mathrm{Ci}$ increase. Low $\mathrm{Cu}$ concentrations in the medium can stimulate oxygen evolution in PSII and, consequently, the flow of electrons (Burda et al. 2002). On the other hand, cultivar 6563 was the only one that had reduced net photosynthetic rate at $\mathrm{Cu}$ concentration $20 \mu \mathrm{M}$ (Figure 2a). Likewise, cultivar 6563 accumulated a large amount of $\mathrm{Cu}$ in plant shoots (Figure 1). This result is justified by the negative correlation between net photosynthetic rate $(\mathrm{A})$ and $\mathrm{Cu}$ concentration in shoots $(\mathrm{Cu} \mathrm{S})$ (Figure 4). $\mathrm{Cu}$ concentration in shoots of cultivar 6563 grown at $\mathrm{Cu}$ concentration $20 \mu \mathrm{M}$ may have induced the formation of reactive oxygen species (ROS), fact that have indirectly compromised the photosynthetic apparatus by inhibiting repairs in the fundamental protein of PSII (Murata et al. 2007).
$\mathrm{G}_{\mathrm{s}}$ decreased at higher $\mathrm{Cu}$ concentrations, and such decrease is likely responsible for transpiration rate $(E)$ decrease, because these two variables $\left(\mathrm{G}_{\mathrm{s}}\right.$ and E) was positively correlated (Figure 4). The lower the stomatal conductance, the lower the water loss; therefore, the greater the water use efficiency. This result was similar in all cultivars grown at $\mathrm{Cu}$ concentrations 20 and $40 \mu \mathrm{M}$ in comparison to the control (Figure 2). However, $\mathrm{G}_{\mathrm{s}}$ decrease seemed not to be the main cause of $\mathrm{A}$ and $\mathrm{A} / \mathrm{Ci}$ decrease when plants were grown at $\mathrm{Cu}$ concentration 40 $\mu \mathrm{M}$, because Ci remained close to $90 \%$ of that observed in the control treatment. Therefore, photosynthesis decrease at $\mathrm{Cu}$ concentration 40 $\mu \mathrm{M}$ may have other reasons. These reasons can be lower concentration of photosynthetic pigments (Table II) or ROS formation caused by $\mathrm{Cu}$ excess (Halliwell and Gutteridge 2015), since these variables had positive and negative correlation to photosynthesis, respectively (Figure 4).

The toxic effect of $\mathrm{Cu}$ concentration $40 \mu \mathrm{M}$ on the concentration of photosynthetic pigments can be attributed to (i) changes in the composition of thylakoids (John et al. 2009); (ii) peroxidation of chloroplast membranes by ROS (Gill and Tuteja 2010); and (iii) formation of metal-pigment complexes (Bazihizina et al. 2015) such as $\mathrm{Mg}$ replacement by Cu in chlorophyll molecules (Küpper et al. 2002). Besides the function of carotenoids in light absorption as accessory pigments in lighttrap complexes, they also act as photo-protective agents of the photochemical apparatus and prevent photo-oxidative damage in chlorophyll molecules (Raven et al. 2007). Assumingly, the chlorophylls concentration decrease at $\mathrm{Cu}$ concentration $40 \mu \mathrm{M}$ (Table II) may have partially resulted from the reduced concentration of carotenoids (Table II).

Plants grown at $\mathrm{Cu}$ concentration 20 or 40 $\mu \mathrm{M}$ in the current study increased SOD activity (Figure 3a) and it happened due to $\mathrm{O}_{2}{ }^{\circ-}$ production, since SOD is responsible for its detoxification; besides, SOD is the first cell defense line against 
ROS (Thounaojam et al. 2012). SOD activity had positive correlation to $\mathrm{Cu}$ concentration (Figure 4), because SOD, and other antioxidant enzymes, often present increased activity at high $\mathrm{Cu}$ concentrations (Zhang et al. 2010). The SOD activity was higher in the shoots than in the roots likely due to the SOD isoforms ( $\mathrm{SOD} \mathrm{Cu} / \mathrm{Zn}$ and SOD Fe) found in chloroplasts (Pilon et al. 2011).

$\mathrm{H}_{2} \mathrm{O}_{2}$ concentrations progressively increased in the shoots and roots of most cultivars (Figure 3b), as observed by Thounaojam et al. (2012). We verified a positive correlation between variables: $\mathrm{H}_{2} \mathrm{O}_{2}$ concentrations, $\mathrm{Cu}$ accumulation and SOD activity (Figure 4). Assumingly, $\mathrm{Cu}$ accumulation in plants had caused $\mathrm{O}_{2}{ }^{\circ}$ production, and it led to SOD activity increase and to consequent $\mathrm{H}_{2} \mathrm{O}_{2}$ concentration increase due to the SOD reaction. It is possible that some other defense line of antioxidant system in cultivar 6410, such as catalase or peroxides, have detoxified $\mathrm{H}_{2} \mathrm{O}_{2}$ in the plant shoots (Choudhary et al. 2007, Gill and Tuteja 2010). According to the MDA concentrations detected in the shoots of cultivars 5958, 5909 and 6410 (Figure $3 \mathrm{c})$, ROS apparently did not cause membrane peroxidation. Chen et al. (2015) observed similar results, they related such outcome to low $\mathrm{Cu}$ transportation from the roots to the shoot. The same results were not recorded for cultivar 6563, which showed high MDA concentration in the shoot of plants grown at $\mathrm{Cu}$ concentration $40 \mu \mathrm{M}$ (Figure $3 c)$. This outcome indicates the possible occurrence of lipid peroxidation. It is possible saying that $\mathrm{H}_{2} \mathrm{O}_{2}$ detoxification was not efficient, since it became $\mathrm{OH}^{*}$ in the presence of $\mathrm{Cu}$ in the Fenton reaction (Gill and Tuteja 2010).

\section{CONCLUSIONS}

High $\mathrm{Cu}$ concentrations in the nutrient solution were harmful to soybean plants. Although each cultivar responded differently to the excess of $\mathrm{Cu}$, none of them showed tolerance to it.
Cultivar M 6410 IPRO was the least affected by the excess of $\mathrm{Cu}(\mathrm{Cu}$ concentration $40 \mu \mathrm{M})$, showing the highest photosynthetic rate and the accumulation of $\mathrm{Cu}$ in the roots, without recording a decrease in the root biomass.

Cultivar DM 6563 RSF IPRO showed similar results to M 6410 IPRO; however, its photosynthetic rate recorded stronger decrease and oxidative damage in plant shoots.

Cultivar NA 5909 RG recorded the highest $\mathrm{Cu}$ translocation to plant shoots; however, the antioxidant system of the plants avoided lipid peroxidation.

DM 5958 RSF IPRO appeared to be the most sensitive cultivar to $\mathrm{Cu}$ excess, its photosynthetic rate and biomass production were significantly lower than in the other cultivars.

Based on these results, we conclude that cultivar M 6410 IPRO has greater potential to be cultivated in environments contaminated by $\mathrm{Cu}$. On the other hand, cultivar DM 5958 RSF IPRO appears not to be recommended for this purpose. However, studies involving field conditions are required to validate such speculations.

\section{ACKNOWLEDGMENTS}

We are grateful to the Conselho Nacional de Desenvolvimento Científico e Tecnológico $(\mathrm{CNPq})$ and the Coordenação de Aperfeiçoamento de Pessoal de Nível Superior - Brazil (CAPES, Finance Code 001) for the scholarships provided and the financial resources made available for this study.

\section{AUTHOR CONTRIBUTIONS}

Raissa Schwalbert led the study, performed the greenhouse work and laboratory analysis and wrote the paper; Lincon Oliveira Stefanello da Silva, Gillian dos Santos Fernandes and Rodrigo Knevitz Hammerschmitt participated on plant growing and copper determination in plants and also contributed 
to the data discussion; Rai Augusto Schwalbert contributed to the data analysis and writing of the paper; Anderson César Ramos Marques, Camila Cavalheiro Costa, and Camila Peligrinotti Tarouco contributed to the photosynthetic and biochemical analysis and data discussion; Gustavo Brunetto and Fernando Teixeira Nicoloso led the study and contributed to the data discussion and writing of the paper.

\section{REFERENCES}

BAZIHIZINA N, COLZI I, GIORNI E, MANCUSO S AND GONNELLI C. 2015. Photosynthesizing on metal excess: Copper differently induced changes in various photosynthetic parameters in copper tolerant and sensitive Silene paradoxa L. populations. Plant Sci 232: 67-76.

BECANA M, MATAMOROS MA, UDVARDI M AND DALTON DA. 2010. Recent insights into antioxidant defenses of legume root nodules. New Phytol 188: 960976.

BRADFORD MM. 1976. A rapid and sensitive method for the quantitation of microgram quantities utilizing the principle of protein-dye binding. Anal Biochem 72: 248-254.

BRUNETTO G, SCHMITT DE, COMIN JJ, MIOTTO A, MORAES MP DE AND HEINZEN J. 2014. Frações de cobre e zinco em solos de vinhedos no Meio Oeste de Santa Catarina. Rev Bras Eng Agrícola e Ambient 18: 805-810.

BURDA K, KRUK J, STRZALKA K AND SCHMID GH. 2002. Stimulation of oxygen evolution in photosystem II by copper ( II ) ions. J Biosci 57: 853-857.

CALOW P. 1991. Physiological costs of combating chemical toxicants: Ecological implications. Comp Biochem Physiol 100: 3-6.

CAMBROLLÉ J, GARCÍA JL, OCETE R, FIGUEROA ME AND CANTOS M. 2013. Growth and photosynthetic responses to copper in wild grapevine. Chemosphere 93: 294-301.

CAMPOS LP, LEITE LFC, MACIEL GA, BRASIL EL AND IWATA B DE F. 2013. Estoques e frações de carbono orgânico em latossolo amarelo submetido a diferentes sistemas de manejo. Pesqui Agropecu Bras 48: 304-312.

CHEN J, SHAFI M, LI S, WANG Y, WU J, YE Z, PENG D, YAN W AND LIU D. 2015. Copper induced oxidative stresses, antioxidant responses and phytoremediation potential of Moso bamboo (Phyllostachys pubescens). Sci Rep 5: 1-9.

CHOUDHARY M, JETLEY UK, ABASH KHAN M, ZUTSHI S AND FATMA T. 2007. Effect of heavy metal stress on proline, malondialdehyde, and superoxide dismutase activity in the cyanobacterium Spirulina platensis-S5. Ecotoxicol and Environ Saf 66: 204-209.

CONRAD KA, DALAL RC, DALZELL SA, ALLEN DE, FUJINUMA R AND MENZIES NW. 2018. Soil nitrogen status and turnover in subtropical leucaena-grass pastures as quantified by $\delta 15 \mathrm{~N}$ natural abundance. Geoderma 313 : 126-134.

EL-MOSHATY FIB, PIKE SM, NOVACKY AJ AND SEHGAL OP. 1993. Lipid peroxidation and superoxide production in cowpea (Vigna unguiculata) leaves infected with tobacco ringspot virus or southern bean mosaic virus. Physiol Mol Plant Pathol 43: 109-119.

EMBRAPA - EMPRESA BRASILEIRA DE PESQUISA AGROPECUÁRIA. 2009. Manual de análises químicas de solos plantas e fertilizantes (Manual of chemical analysis of soils, plants and fertilizers), $2^{\mathrm{a}}$ ed., Brasília, $627 \mathrm{p}$.

EMBRAPA - EMPRESA BRASILEIRA DE PESQUISA AGROPECUÁRIA. 2014. Clima Temperado. (Pelotas, RS). Indicações técnicas para a cultura da soja no Rio Grande do Sul e em Santa Catarina. Safras 2014/2015 e 2015/2016, 40 a Reunião de Pesquisa de Soja da Região Sul. 124 p. (Documentos/Embrapa Clima Temperado, ISSN 1516-8840;382).

FELLET G, MARCHIOL L, PEROSA D AND ZERBI G. 2007. The application of phytoremediation technology in a soil contaminated by pyrite cinders. Ecol Eng 31: 207-214.

GIANNOPOLITIS CN, AND RIES SK. 1977. Superoxide Dismutases I. Occurrence in higher plants. Plant Physiol 59: 309-314.

GILL SS AND TUTEJA N. 2010. Reactive oxygen species and antioxidant machinery in abiotic stress tolerance in crop plants. Plant Physiol 48: 909-930.

GIROTTO E, CERETTA CA, ROSSATO LV. FARIAS JG, TIECHER TL, DE CONTI L, SCHMATZ R, BRUNETTO G, SCHETINGER MRC AND NICOLOSO FT. 2013. Triggered antioxidant defense mechanism in maize grown in soil with accumulation of $\mathrm{Cu}$ and $\mathrm{Zn}$ due to intensive application of pig slurry. Ecotoxicol Environ Saf 93: 145155.

GIROTTO E, ET AL. 2016. Plant Physiology and Biochemistry Biochemical changes in black oat (Avena strigosa Schreb) cultivated in vineyard soils contaminated with copper. Plant Physiol Biochem 103: 199-207.

GONZÁLEZ-MENDOZA D, ESPADAS Y GIL F, ESCOBOZA-GARCIA F, SANTAMARÍA JM AND ZAPATA-PEREZ O. 2013. Copper stress on photosynthesis of black mangle (Avicennia germinans). An Acad Bras Cienc 85: 665-670.

HALL JL. 2002. Cellular mechanisms for heavy metal detoxification and tolerance. J Exp Bot 53: 1-11.

HALLIWELL B AND GUTTERIDGE JMC. 2015 Free radicals in Biology and medicine, $5^{\text {th }}$ ed., United Kingdom, Oxford University Press, 896 p. 
HISCOX JD AND ISRAELSTAM GF. 1979. A method for the extraction of chlorophyll from leaf tissue without maceration. Can J Bot 57: 1332-1334.

JOHN R, AHMAD P, GADGIL K AND SHARMA S. 2009. Heavy metal toxicity: Effect on Plant growth, biochemical parameters and metal accumulation by Brassica juncea L. Int J Plant Prod 3: 65-76.

KABATA-PENDIAS A. 2011. Trace elements in soils and plants, $534 \mathrm{p}$.

KÜPPER H, ŠETLÍK I, SPILLER M, KÜPPER FC AND PRÁŠIL O. 2002. Heavy metal-induced inhibition of photosynthesis: Targets of in vivo heavy metal chlorophyll formation. J Phycol 38: 429-441.

LASAT MM. 2002. Phytoextraction of toxic metals: A review of biological mechanisms. J Environ Qual 31: 109-120.

LÊ S, JOSSE J AND HUSSON F. 2008. FactoMineR: An R package for multivariate analysis. J Stat Softw 25: 1-18.

LICHTENTHALER HK. 1987. Chlorophylls and carotenoids: Pigments of photosynthetic biomembranes. Method Enzymol 148: 350-382.

LORETO F AND VELIKOVA V. 2001. Isoprene produced by leaves protects the photosynthetic apparatus against ozone damage, quenches ozone products, and reduces lipid peroxidation of cellular membranes. Plant Physiol 127: 1781-1787.

MARASTONI L, SANDRI M, PII Y, VALENTINUZZI F, BRUNETTO G, CESCO S AND MIMMO T. 2019. Synergism and antagonisms between nutrients induced by copper toxicity in grapevine rootstocks : Monocropping vs. intercropping. Chemosphere 214: 563-578.

MASSOCATTO CL, DINIZ KM, BOLSON J, GONÇALVES JÚNIOR AC AND DRAGUNSKI DC. 2013. Quantificação de elementos potencialmente tóxicos presentes em diferentes cultivares de grãos de soja e milho comercializados na região noroeste do Paraná. Sci Agrar Parana 12: 182-192.

MiOTTO A, CERETTA CA, BRUNETTO G, NICOLOSO FT, GIROTTO E, FARIAS JG, TIECHER TL, DE CONTI L AND TRENTIN G. 2014. Copper uptake, accumulation and physiological changes in adult grapevines in response to excess copper in soil. Plant Soil 374: 593-610.

MURAKAMI M AND AE N. 2009. Potential for phytoextraction of copper, lead, and zinc by rice (Oryza sativa L.), soybean (Glycine $\max$ [L.] Merr.), and maize (Zea mays L.). J Hazard Mater 162: 1185-1192.

MURATA N, TAKAHASHI S, NISHIYAMA Y AND ALLAKHVERDIEV SI. 2007. Photoinhibition of photosystem II under environmental stress. Biochim Biophys Acta 1767: 414-421.

PIERZYNSKI GM, SCHNOOR JL, SCHNOOR MK, BANKS MK, TRACY JC, LICHT LA AND ERICKSON, LE. 1994. Vegetative Remediation at Superfund Sites. In: Hester RE and Harrizon RM. Mining and its Environmental
Impact (Royal Soc Chem Issues in Environ Sci Technol 1). p. 49-69.

PILON M, RAVET K AND TAPKEN W. 2011. The biogenesis and physiological function of chloroplast superoxide dismutases. Biochim Biophys Acta 1807: 989-998.

PINHEIRO J, ET AL. R Core Team 2017._nlme: Linear and Nonlinear Mixed Effects Models. R package version 3.1131, <URL: https://CRAN.R-project.org/package=nlme $>$.

RAVEN PH, EVERT RF AND EICHHORN SE. 2007 Biologia vegetal. Rio de Janeiro: Guanabara Koogan, $7^{\mathrm{a}}$ ed., 728p.

R CORE TEAM. 2017. R: A language and environment for statistical computing. R Foundation for Statistical Computing, Vienna, Austria. URL https://www.R-project. org/..

RNC - REGISTRO NACIONAL DE CULTIVARES. 2019. Disponível em: http://www.agricultura.gov.br/guia-deservicos/registro-nacional-de-cultivares-rnc Acessado em: 21 out. 2019.

SÁNCHEZ-PARDO B, FERNÁNDEZ-PASCUAL M AND ZORNOZA P. 2012. Copper microlocalisation, ultrastructural alterations and antioxidant responses in the nodules of white lupin and soybean plants grown under conditions of copper excess. Environ Exp Bot 84: 52-60.

SILVA MLDS, VITTI GC AND TREVIZAM AR. 2014. Heavy metal toxicity in rice and soybean plants cultivated in contaminated soil. Rev Ceres 61: 248-254.

SOTO P, GAETE H AND HIDALGO ME. 2011. Assessment of catalase activity, lipid peroxidation, chlorophyll a, and growth rate in the freshwater green algae Pseudokirchneriella subcapitata exposed to copper and zinc. Lat Am Jo Aquat Res 39: 280-285.

SŁOMKA A, LIBIK-KONIECZNY M, KUTA E AND MISZALSKI Z. 2008. Metalliferous and non-metalliferous populations of Viola tricolor represent similar mode of antioxidative response. J Plant Physiol 165: 1610-1619.

THOUNAOJAM TC, PANDA P, MAZUMDAR P, KUMAR D, SHARMA GD, SAHOO L AND PANDA SK. 2012. Excess copper induced oxidative stress and response of antioxidants in rice. Plant Physiol Biochem 53: 33-39.

TIECHER TL ET AL. 2016a. The potential of Zea mays L. in remediating copper and zinc contaminated soils for grapevine production. Geoderma 262: 52-61.

TIECHER TL, TIECHER T, CERETTA CA, FERREIRA PAA, NICOLOSO FT, SORIANI HH, TASSINARI A, PARANHOS JT, DE CONTI L AND BRUNETTO G. 2016b. Physiological and nutritional status of black oat (Avena strigosa Schreb.) grown in soil with interaction of high doses of copper and zinc. Plant Physiol Biochem 106: 253-263.

WHITING SN, ET AL. 2004. Research priorities for conservation of metallophytes biodiversity and their potential for restoration and site remediation. Restor Ecol 12: 106-116. 
YANG Y, SUN C, YAO Y, ZHANG Y AND ACHAL V. 2011. Growth and physiological responses of grape (Vitis vinifera "Combier") to excess zinc. Acta Physiol Plant 33: 1483-1491.

YRUELA I. 2013. Transition metals in plant photosynthesis. Metallomics 5: 1090-1109.

ZHANG L, PAN Y, LV W AND XIONG ZT. 2014. Physiological responses of biomass allocation, root architecture, and invertase activity to copper stress in young seedlings from two populations of Kummerowia stipulacea (maxim.) Makino. Ecotoxicol Environ Saf 104: 278-284.

ZHANG H, ZHANG F, XIA Y, WANG G AND SHEN Z. 2010. Excess copper induces production of hydrogen peroxide in the leaf of Elsholtzia haichowensis through apoplastic and symplastic CuZn-superoxide dismutase. J Hazard Mater 178: 834-843.

ZHU Z, WEI G, LI J, QIAN Q AND YU J. 2004. Silicon alleviates salt stress and increases antioxidant enzymes activity in leaves of salt-stressed cucumber (Cucumis sativus L.). Plant Sci 167: 527-533.

ZOUARI M, BEN AHMED C, ZORRIG W, ELLOUMI $\mathrm{N}$, RABHI M, DELMAIL D, BEN ROUINA B, LABROUSSE P AND BEN ABDALLAH F. 2016. Exogenous proline mediates alleviation of cadmium stress by promoting photosynthetic activity, water status and antioxidative enzymes activities of young date palm (Phoenix dactylifera L.). Ecotoxicol Environ Saf 128: 100 108. 